研 究

\title{
PSH-MIM 法によって作製された多孔質ステンレス鋼の電気化学的特性
}

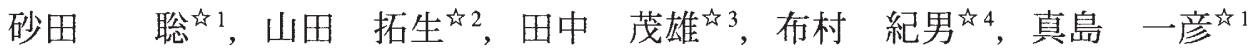 \\ 4 1 富山大学大学院理工学研究部ナノ・新機能材料学域ナノマテリアル・システムデザイン学系, † 930-8555 富山市五福 3190.

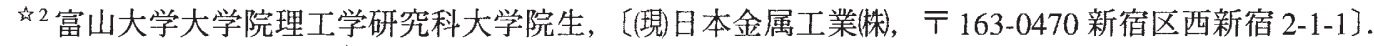

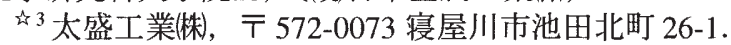 \\ 神富山大学総合情報基盤センター, 产930-8555 富山市五福 3190 .
}

\section{Electrochemical Characteristics of Dissolution for Stainless Steel Produced by PSH-MIM Process}

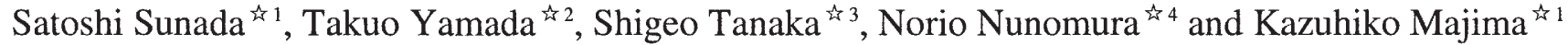 \\ 'Graduate School of Science and Engineering for Research, University of Toyama, 3190 Gofuku, Toyama 930-8555, Japan. \\ ${ }^{42}$ Graduate Student, University of Toyama, [Present Address: Nippon Metal Industry CO.,LTD., \\ 2-1-1 Nishi-Shinjuku, Shinjuku-ku, Tokyo 163-0470, Japan]. \\ i3 3 Taisei Kogyo CO., LTD., 26-1 Ikeda-kitamachi, Neyagawa 572-0073, Japan. \\ ${ }^{2}{ }^{4}$ Information Technology Center, University of Toyama, 3190 Gofuku, Toyama 930-8555, Japan.
}

Received January 19, 2009

\section{SYNOPSIS}

Metal injection molding (MIM), one of the powder metallurgy processes, has attracted considerable interest because of the advantage of better formability to fabricate complex shape products without machining and welding. In this experiment, the specimens prepared by the conventional MIM process and the powder space holder-metal injection molding process (PSH-MIM process) were used, and their corrosion behaviors were investigated through the electrochemical procedures such as potendiodynamic polarization curve measurement, electrochemical impedance spectroscopy (EIS) and the coulostat method. The porous specimen prepared by PSH-MIM process was corroded more easily than the one prepared by the conventional MIM process. This is because the PSH-MIM specimen has the greater surface area than the conventional specimen. The EIS and the coulostat measurement methods were confirmed to be quite effective for the measurement of corrosion behavior of the porous materials.

\section{KEY WORDS}

Stainless steel, powder space holder-metal injection molding, electrochemical impedance spectroscopy, coulostat method

\section{1 緒言}

一般溶製 (Ingot Material, 以下 I/M と略記する) 法にて製造 されるステンレス鋼は大半が板材, 線材, 管材で製造されて いるため, 複雑な形状をしている自動車部品にそのまま用い ることが困難である。そこで複雑形状に適合するために I/M 材に代わり粉末冶金法を利用して部品を製造する方法が普及 している. 焼結体の製造方法としては常温で金型に入れた粉 末を上下パンチ棒で圧縮成型し, 型から外して焼結させる通 常成型 (Powder Metallurgy, 以下 P/M と略記する) 法, 粉末を スラリー状にして圧力をかけて型に射出成形し, 型から外し て焼結する MIM 法 (Metal Injection Molding)などさまざまで ある.この中で特にMIM法で製造された焼結体は機械的な性 質が I/M材に非常に近いことが報告されている ${ }^{1,2)}$. また著者
ら 3-6) は過去にP/MやMIM 法により作製されたステンレス鋼 の耐食性に関する報告をしてきた。これらの結果よりMIM法 により作製されたステンレス鋼の耐食性は $\mathrm{I} / \mathrm{M}$ 材に近いこと が明らかとなった。

一方, 近年では既存の金属材料を多孔質化することにより, 付加価値の高い機能性材料を開発する研究が盛んに行われる ようになり, 新たな材料として注目されている. パウダース ペースホルダーMIM (Powder Space Holder MIM, 以下 PSHMIM と略記する) 法は, 従来の MIM 法を応用し, 金属粉末と バインダーから構成されるMIM原料に気孔形成材を添加し, 成形・脱脂・焼結により金属製多孔質材料の作製を可能にし た技術である．この技術によって作製された多孔質構造を有 するポーラス金属は, 軽量で, 大きい比強度・断熱性・防音・ 
防振特性を持つために建材用断熱・防音材や金属フィルター, 衝撃吸収材料，熱交換材料への利用が期待されている. しか し製造されてから歴史は浅く,多孔質材の耐食性に関する研 究は少ないのが現状である.

そこで本研究では, 平均気孔径·気孔率の異なるPSH-MIM 法で作製されたSUS316L鋼および気孔を有さないMIM 法で 作製された SUS316́L鋼を使用し, $\mathrm{H}_{2} \mathrm{SO}_{4}$ 水溶液中における腐 食特性を電気化学的な方法を用いて測定し, 多孔質ステンレ 又鋼の基本的な腐食挙動を明らかにすることを目的にした.

\section{2 実験方法}

2.1 試料の作製

PSH-MIM 法によって作製された試料の基本的な腐食挙動 を調べるために本実験で使用した試料は, 気孔径・気孔率の 異なる2種の多孔質 SUS316L 鋼である. 各試料の平均気孔径 および気孔率をTable 1に示した.ここで本実験に使用した試 料は, 球状の気孔が連続している気孔構造であるために, Fig.1に示すように気孔同士のつなぎ目の径を気孔径として定 義し，その值を測定した。これらの試料は以後, 気孔径の大 きいほうから Sample A, Sample B と記す。また比較材料とし て MIM 法で作製された SUS316L 鋼を用意した。試料は，い ずれも厚さ $3 \mathrm{~mm}$ の板状で $10 \mathrm{~mm} \times 15 \mathrm{~mm}$ の形状である.

これらの試料に関し前処理として,気孔を有さないMIM材 は試料表面を＃80番から\#2000番までの耐水エメリ一紙を用 いて湿式研磨し，アルコール洗浄後，アセトン中で $300 \mathrm{~s}$ 間超 音波洗浄を行った. その後, 試料をホルダーに装着し, 反応 面積 $\left(1 \times 10^{-4}\right) \mathrm{m}^{2}$ を残してシリコンラバーを塗布し, 絶縁し た。一方多孔質な構造を持つ PSH-MIM 材は，湿式研磨せず

Table 1 Pore size and porosity of specimens used in this experiment.

\begin{tabular}{c|c|c|c} 
& Specimen & pore size & porosity \\
\hline Sample A & Porous-SUS316L & $12 \mu \mathrm{m}$ & $64 \%$ \\
\hline Sample B & Porous-SUS316L & $1.5 \mu \mathrm{m}$ & $50 \%$ \\
\hline
\end{tabular}

に超音波洗浄を行った後, MIM材と同様な形状のシール方法 で試料面を残し, シリコーンゴムで絶縁した.これらの試料 を電気化学的测定に用いた.

\section{2 分極曲線测定}

PSH-MIM 法により作製されたSUS316L鋼のカソード反応 およびアノード反応の基本的な腐食特性を調べるために分極 曲線を測定した. 用いた試験装置図をFig.2に示した. 本測定 システムは恒温槽中にアノード室とカソード室からなる $2 \times$ $10^{-4} \mathrm{~m}^{-3}$ の $\mathrm{H}$ 型電解槽, 中間槽, $\mathrm{Ag} / \mathrm{AgCl}\left(3.33 \mathrm{kmol} \cdot \mathrm{m}^{-3} \mathrm{KCl}\right)$ 照合電極をブリッジ, 塩橋でつなぐことによって構成されて いる. 試料電極, 白金電極, および照合電極はポテンショス タットに接続し, さらにポテンショスタットをパーソナルコ ンピューターに接続することで実験結果を自動記録するよう にした. なお, 本論文の電位は全て $\mathrm{Ag} / \mathrm{AgCl}$ 照合電極を基準 に示した.

試験水溶液には $0.5 \mathrm{kmol} \cdot \mathrm{m}^{-3} \mathrm{H}_{2} \mathrm{SO}_{4}$ 水溶液を用いた。試験 前にあらかじめ $298 \mathrm{~K}$ に保持しながら純窒素ガスで十分に脱 酸素した.この電極を試験溶液に $1.8 \mathrm{ks}$ 間浸漬した後, ポテン ショスタットおよび付属のコンピュータで $-0.8 \mathrm{~V}$ から $1.2 \mathrm{~V}$ まで掃引速度 $0.5 \times 10^{-3} \mathrm{~V} \cdot \mathrm{s}^{-1}$ で掃引し電流密度を記録した.

\section{3 試料表面の組織観察}

分極曲線測定終了後, 試料の腐食形態を調べるために走査 電子䫓微鏡 (Scanning Electron Microanalysis: 以降SEM と略記 する) を用いて腐食表面の観察を行った．分極曲線測定終了 後, 試料を純水, アセトンを用いて超音波洗浄し, 真空デシ ケー夕内で乾燥させ, SEMを用いて腐食表面の金属組織観察 を行った. また腐食前の試料も同様に処理を行い観察し，腐 食前後で比較を行った.

\section{4 電気化学インピーダンス測定}

電極界面の等価回路をシミュレートし, 律速過程の解析や 腐食のメカニズム等の解析に電気化学インピーダンス分光法 (Electrochemical Impedance Spectroscopy: 以降 EIS 法と略記す る)がしばしば用いられている7).この方法により電極界面に おける諸現象を電気的な等価回路にシミュレートし, 等価回 路を構成するパラメータの值を決定することができる.
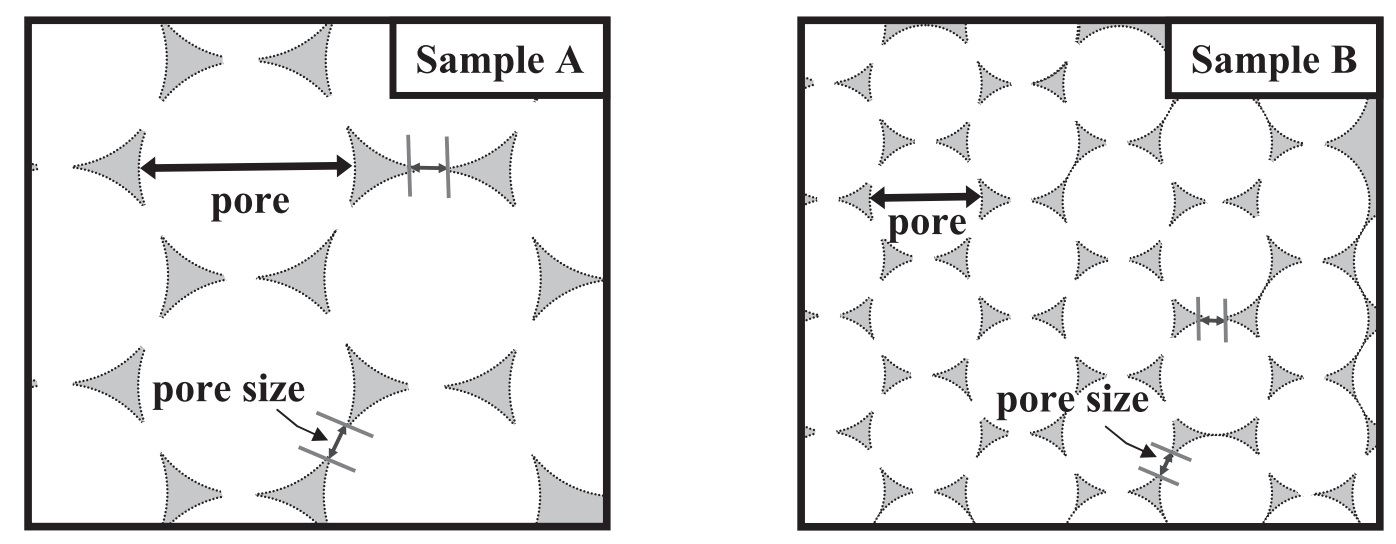

Fig.1 Schematic microstructure of Type 316 stainless steels produced by PSH-MIM process. 


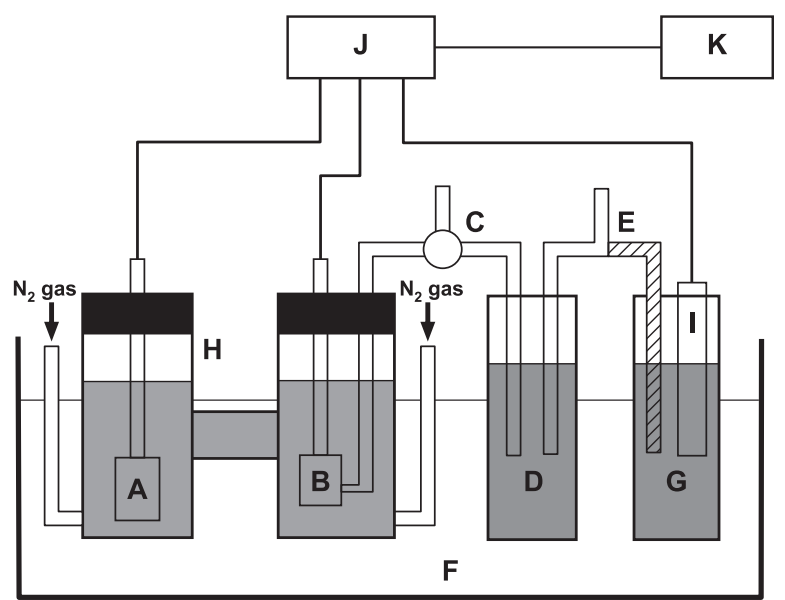

A: Counter electrode(Pt) B: Specimen C: Bridge D: Intermediate beake E: Salt bridge F: Water bath G: Saturated potassium chloride solution H: Electrochemical cell I: Reference electrode J: Potentiostat K: Computer

Fig.2 Schematic diagram of apparatus for the measurement of the potentiodynamic polarization curve.

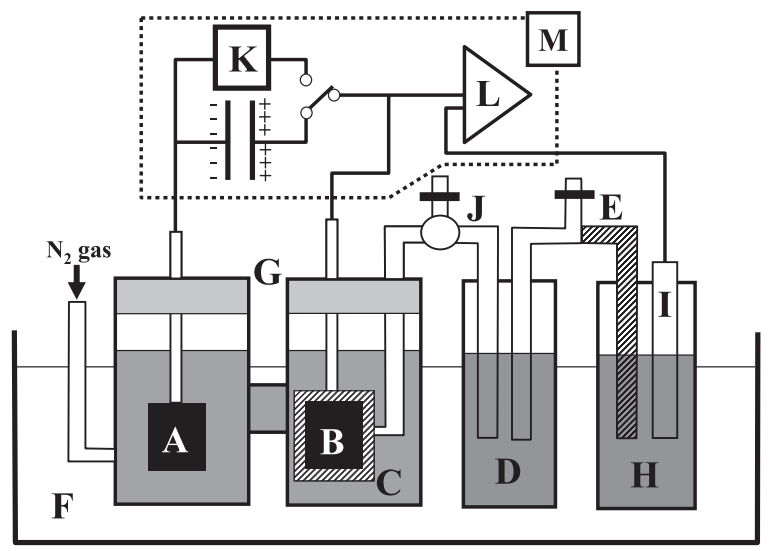

A: Counter electrode(Pt) B: Specimen C: Electric double layer capacitance D: Intermediate beaker E: Salt bridge F: Water bath G: Electrochemical cell H: Saturated potassium chloride solution I: Reference electrode J: Bridge K: D.C.Power supply L: Amplifier M: Coulostat

Fig.3 Schematic diagram of apparatus for the measurement of the Coulostat.

試験溶液には $0.5 \mathrm{kmol} \cdot \mathrm{m}^{-3} \mathrm{H}_{2} \mathrm{SO}_{4}$ 水溶液を用いた。試験溶 液は，上述した同様の方法で脱酸素を施し，温度を $298 \mathrm{~K} に$ 保った。試験開始前に予め電極を $1.8 \mathrm{ks}$ 間保持した後, 自然 浸漬電位を測定した。このときの自然浸漬電位で電位を規制 し, 振幅 $1.0 \times 10^{-2} \mathrm{~V}$ の交流電圧を重畳した. 交流電圧の周波 数を $100 \mathrm{kHz}$ から $1 \mathrm{mHz}$ まで，周波数が 0.1 倍変化する間に 5 点インピーダンスを測定した。得られたインピーダンスの 実部ならびに虚部の值を複素平面上に描いた。この場合, 虚 部のマイナスが第 1 象限と第 2 象限になるように描いた。测 定值として描かれた複素平面上のインピーダンス軌跡を後述 する解析法により解析し, 電極界面の情報を示すパラメータ をコンピュータでシミュレートし，決定した.
2.5 クーロスタット法による測定

クーロスタット法は, Sato ( $^{8)}$ によってその有効性が示さ れ, 電気化学インピーダンス測定法と同時に, 電気二重層容 量, 電荷移動抵抗, 時定数を求めることができる方法の 1 つ である. 電極溶液界面の電気二重層容量に充電し, その電極 界面反応による放電特性から, 分極抵抗, 電気二重層容量お よび時定数を求めた. Fig.3はその装置模式図である. 装置に 設けたコンデンサに貯えた電荷を試料金属に瞬時に移動させ, その電位を平衡状態から高電位側に 30 から $50 \mathrm{mV}$ 変化させ る. その後, 与えられた電荷は電極面で進行する腐食反応に よって消費され，それに伴って高電位側に移行していた電位 は元の電位に戻る.この過程を電位一時間曲線として測定し, 
その減衰特性から, 分極抵抗, 電気二重層容量および時定数 を求めた.

\section{3 実験結果および考察}

3.1 分極曲線測定

PSH-MIM法により作製されたSUS316L鋼のカソード領域 およびアノード領域の基本的な腐食特性を調べるために分極 曲線を測定した. Fig.4には本報の基準にしている気孔を有さ ないMIM 法で作製された SUS316L 鋼の分極曲線測定の結果 および多孔質な構造を持つPSH-MIM 法により作製された気 孔径・気孔率の異なる 2 種のSUS316L鋼の分極曲線の結果を 一括して示した。 縦軸は $\mathrm{Ag} / \mathrm{AgCl}\left(3.33 \mathrm{kmol} \cdot \mathrm{m}^{-3} \mathrm{KCl}\right)$ 電極基 準の電位を示しており, 横軸は各電位における電流密度を対 数で示している.

本実験で用いた全ての試料において-0.80Vから-0.30Vまで カソード領域, $-0.30 \mathrm{~V}$ から $-0.25 \mathrm{~V}$ まで活性態領域, $-0.25 \mathrm{~V}$ から $1.00 \mathrm{~V}$ まで不動態領域, $1.00 \mathrm{~V}$ から $1.20 \mathrm{~V}$ まで過不動態 領域のある典型的なステンレス鋼の分極曲線を示した. 各試 料の電流方向が逆転する腐食電位は, MIM 法で作製された

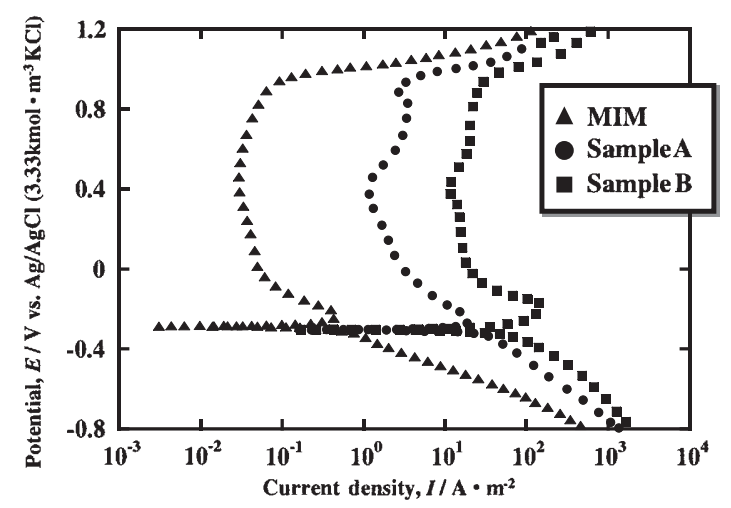

Fig.4 Polarization curves of Type 316 stainless steels produced by MIM and PSH-MIM process in the solution of $0.5 \mathrm{kmol}$ $\mathrm{m}^{-3} \mathrm{H}_{2} \mathrm{SO}_{4}$ at $298 \mathrm{~K}$.

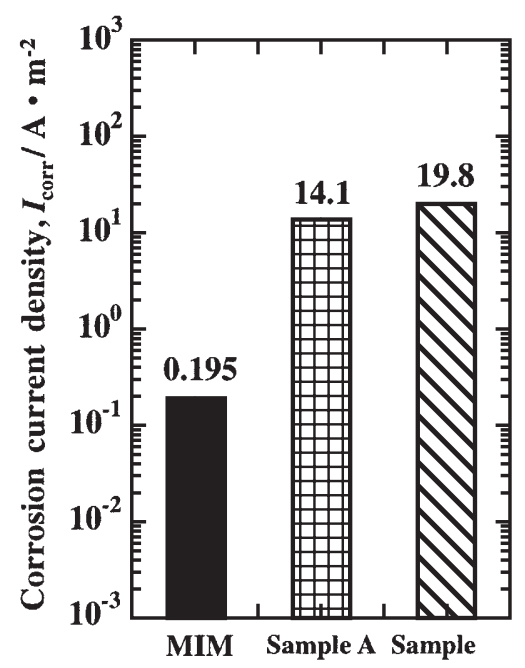

試料では $-0.285 \mathrm{~V}$, Sample A では-0.305V, Sample B では $-0.305 \mathrm{~V}$ であり, 気孔径・気孔率により腐食電位が高低する 傾向は見られず, $-0.285 \mathrm{~V}$ から $-0.305 \mathrm{~V}$ の狭い電位範囲にその 值を示した. また全ての試料でカソード領域の電位 $-0.400 \mathrm{~V}$ から $-0.500 \mathrm{~V}$ までの電位範囲において, 水素発生型の還元反 応を示す典型的なターフェル勾配を示した. 各試料のター フェル勾配は, MIM 法で作製された試料では一 $0.060 \mathrm{~V} /$ decade, Sample Aでは-0.070 V/decade, Sample Bでは-0.060 V/decadeであり, 3 種の試料ともにほぼ同じ勾配を示した. こ れらのターフェル勾配がほぼ等しいことから反応機構がほぼ 同一と考元られ9), カソード領域ではいずれの試料において も, $\mathrm{H}_{2}$ 発生型のカソード反応が同じ反応機構で起こっている ものと考えられる. 一方, ターフェル外挿法 ${ }^{10)}$ を用いて自然 浸漬時の腐食速度を表すパラメータである腐食電流密度 $i_{\text {corr }}$ および不動態領域の+0.40Vにおける腐食速度を表すパラ メータである不動態維持電流密度 $i_{\mathrm{p}}$ を算出したところ, 気孔 径・気孔率の違いによって大きな差が生じた. そこでFig.5に は各試料の腐食電流密度 $i_{\text {cor }}$ および各試料の不動態維持電流 密度 $i_{\mathrm{p}}$ を棒グラフにして示した. 自然浸漬時の腐食速度を表 すパラメータである腐食電流密度 $i_{\text {corr }}$ は, MIM 法で作製され た試料では $0.195 \mathrm{~A} \cdot \mathrm{m}^{-2}$, Sample A では $14.1 \mathrm{~A} \cdot \mathrm{m}^{-2}$, Sample Bでは $19.8 \mathrm{~A} \cdot \mathrm{m}^{-2}$ であった.この結果から MIM 材を基準に多 孔質材を比較したところ, Sample A では 72 倍に増加し, Sample B では 102 倍に増加した。 一方, 不動態領域の +0.40 Vにおける不動態電流密度 $i_{\mathrm{p}}$ は, MIM法で作製された試料で は $0.0288 \mathrm{~A} \cdot \mathrm{m}^{-2}$, Sample A では $1.14 \mathrm{~A} \cdot \mathrm{m}^{-2}$, Sample B では $11.2 \mathrm{~A} \cdot \mathrm{m}^{-2}$ であった.この結果からも同様にMIM材を基準に 多孔質材を比較したところ, Sample A では 40 倍に増加し, Sample B では388 倍に增加した. 以上のように気孔径・気孔 率の異なる試料におりる, 腐食電流密度 $i_{\mathrm{cor}}$ と不動態維持電 流密度 $i_{\mathrm{p}}$ の大きな差は, MIM材に対して見かけ上 $\left(1 \times 10^{-4}\right) \mathrm{m}^{2}$ に面積を規制した多孔質材での実表面積の差が大きく関係し ているものと考えられる.

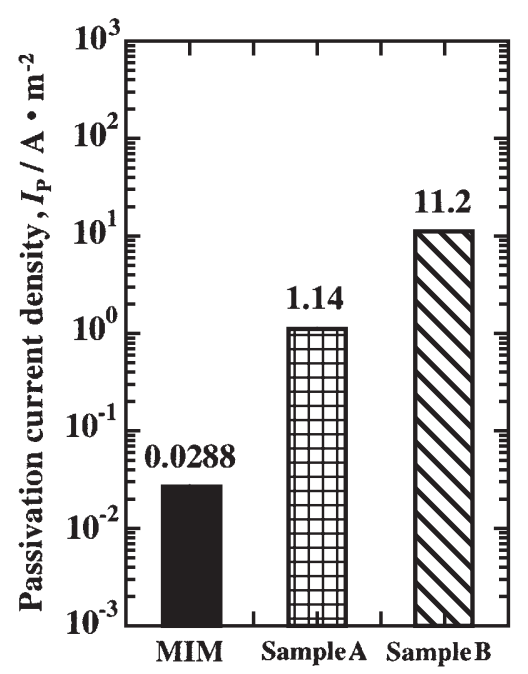

Fig.5 Corrosion current density and Passivation current density of Type 316 stainless steel in the solution of $0.5 \mathrm{kmol} \cdot \mathrm{m}^{-3} \mathrm{H}_{2} \mathrm{SO}_{4}$ at $298 \mathrm{~K}$. 


\section{2 試料表面の組織観察}

多孔質材の表面積の大きさが，腐食電流密度 $i_{\text {corr }}$ と不動態 維持電流密度 $i_{\mathrm{p}}$ を決定していると考えられるため, 試料表面 をSEM で観察をした。

Fig.6には各試料の分極曲線測定前後における試料表面の組 織写真を示した. Fig.6の左側に示した腐食前の MIM 材は気 孔を有さないのに対し, 多孔質材は特有の網目状の組織が観 察される. また気孔径の違いによっても組織が大きく異なる ことを示している.一方Fig.6の右側に示した腐食後は, MIM 材はわずかに空隙が腐食するのに対し，多孔質材は網目状の 組織が全体的に細くなっている.これは溶液が試料内部まで 染み渡り, 試料全体で腐食が進行しているためだと考元られ る.この結果からも, PSH-MIM 材はMIM 材に対し組織が多 孔質であり，溶液が試料内部まで浸透し全体的に腐食が進行 するものと考えられる.
3.3 電気化学インピーダンス測定

分極曲線で求まる腐食電流密度 $i_{\mathrm{corr}}$ をさらに詳細に検討す るため，EIS 法による測定を行った．この EIS 法による測定 は電極界面の現象を電気的な等価回路にシミュレートし, 律 速過程の解析や腐食のメカニズム等の解析にしばしば用いら れている ${ }^{11)}$. 本実験ではEIS 法を利用して電極界面の情報を 電気的等価回路に置き換え，その等価回路を構成するパラ メータの值を求めた.

Fig.7には本実験で用いた試料の自然浸漬電位 $E_{\mathrm{cor}}$ における インピーダンス線図を示した. 3つの試料ともに $100 \mathrm{kHz}$ を含 む高周波数領域にて電荷移動抵抗 $R_{\mathrm{cl}}$ および電気二重首容量 $C_{\mathrm{d} 1}$ から構成される容量性半円を示した後, 低周波領域にて第 二の容量性半円を示した.この第二の容量性半円は, 拡散過 程を表す軌跡 ${ }^{12)}$ の一部あるいは皮膜形成に関する軌跡と報告 されている. そこでこれらのどちらかを確かめるために，拡

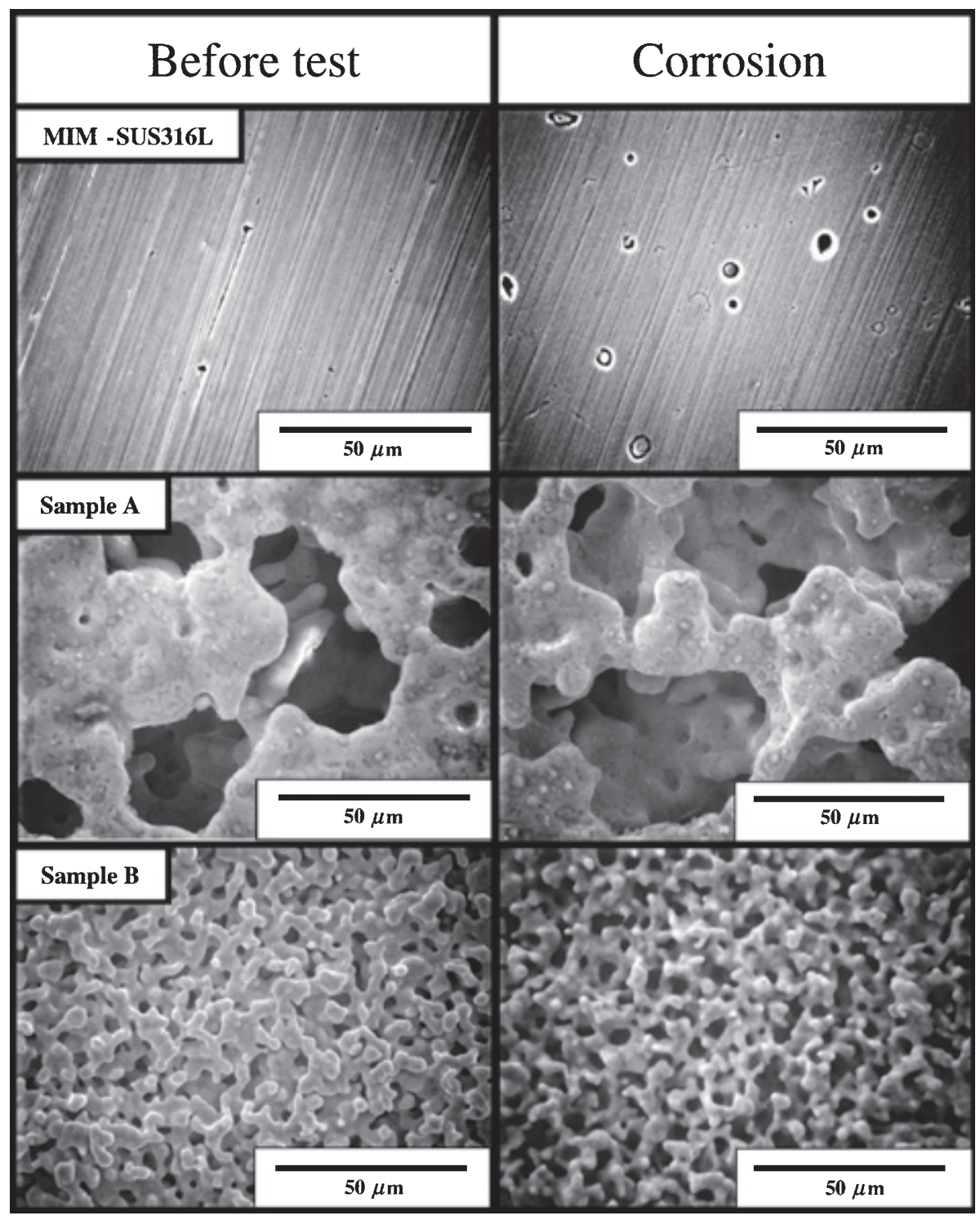

Fig.6 SEM micrographs of the surfaces section for the specimens before and after the potentiodynamic polarization curve measurement in the solution of $0.5 \mathrm{kmol} \cdot \mathrm{m}^{-3} \mathrm{H}_{2} \mathrm{SO}_{4}$ at $298 \mathrm{~K}$. 

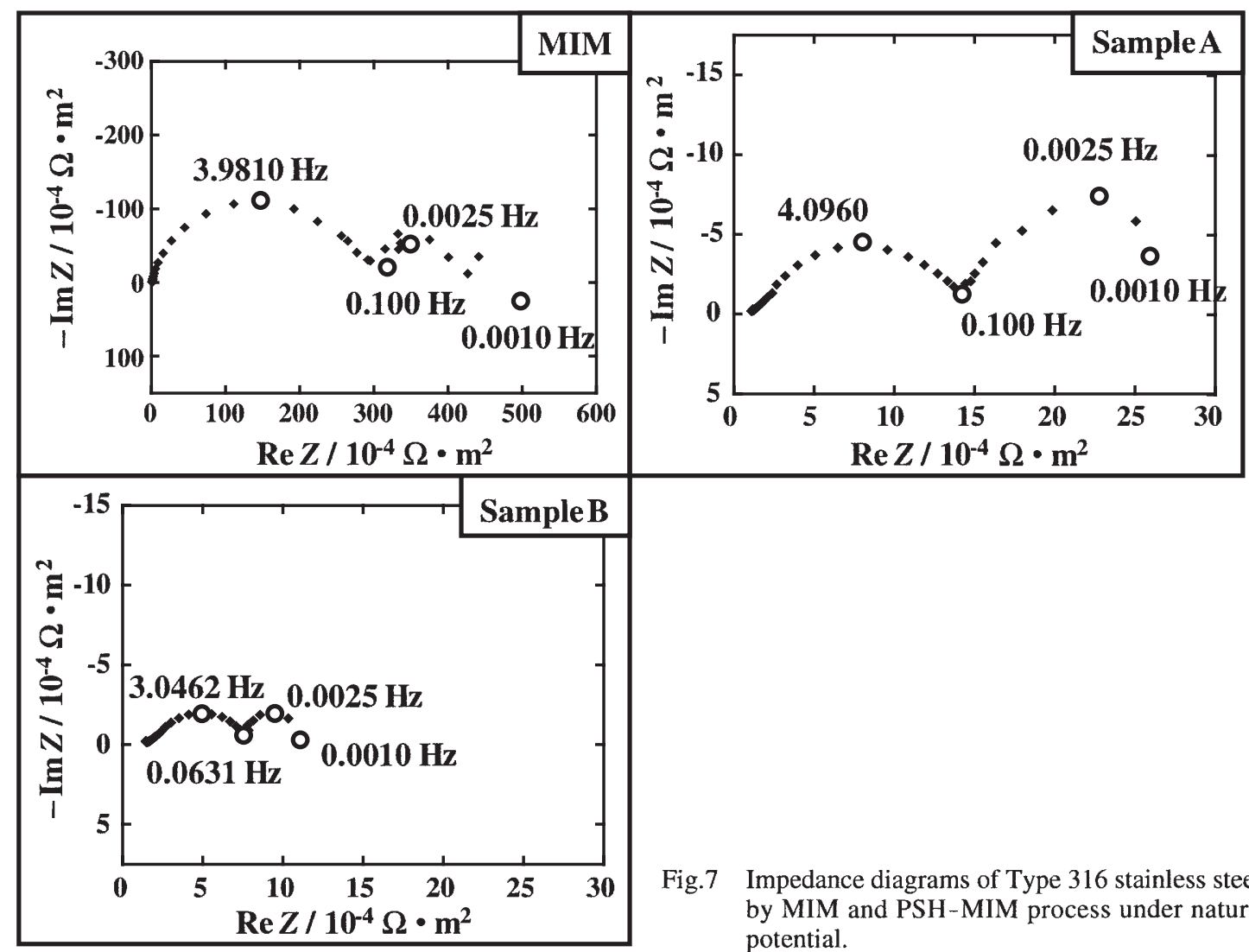

Fig.7 Impedance diagrams of Type 316 stainless steels produced by MIM and PSH-MIM process under natural electrode potential.

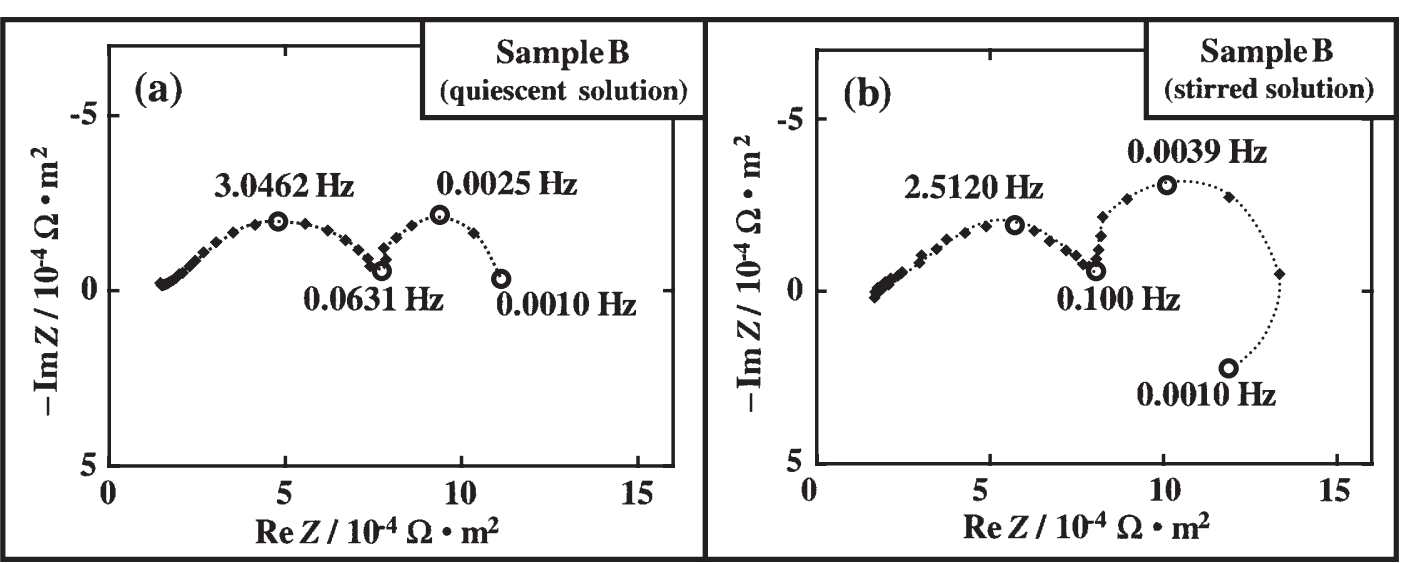

Fig.8 Impedance diagrams of Type 316 stainless steels produced by PSH-MIM process under natural electrode potential, (a) quiescent solution and (b) stirred solution.

散過程に影響を及ぼす擋拌溶液中でのEIS 法による測定を 行った. Fig.8にはSample B の自然浸漬電位 $E_{\mathrm{corr}}$ におけるイン ピーダンス線図を示した. Fig.8 (a) が静止溶液中のインピー ダンス線図を, Fig.8 (b) が摚找溶液中のインピーダンス線図 を示している.これらの結果から擋拌の有無によらず低周波 領域での第二の容量性半円は実験誤差範囲内で差異はほとん ど見られなかった. 従って低周波領域での第二の容量性半円 は皮膜形成に関するインピーダンス軌跡であると考えられる.

Fig.7に示したような電荷移動過程における中間吸着体反応
を伴うインピーダンス軌跡は杉本ら ${ }^{11,13,14)}$ Epelboin ${ }^{15-17)} ら$ Armstrong $ら^{18-20)}$, Keddam $ら^{21-23)}$, 原 ${ }^{24)}$, 板垣ら ${ }^{25)}$ によ て導出されている.著者らはこれらを参考にしてすでに理論 式である (1) 式を導出している7). そこで, この(1) 式のイン ピーダンスと測定で得られるインピーダンス軌跡が一致する ように各々のパラメータの值を試行錯䛊法により決定した.

$$
\frac{1}{Z}=\frac{1+\left(j \omega \tau_{0}\right)^{\gamma}}{R_{\mathrm{ct}}}+\sum_{i=1}^{n} \frac{1}{R_{i}\left(1+j \omega \tau_{i}\right)}
$$


ここでZは電極インピーダンス, $R_{\mathrm{ct}}$ は電荷移動抵抗， $C_{\mathrm{dl}}$ は電 気二重層容量, $j$ は虚数単位, $\omega$ は規制電位に重畳する交流成 分の角周波数, $\gamma$ は $0<\gamma \leq 1$ の範囲内で変化する電極面の粗 さ ${ }^{24)}$ に起因する補正パラメー夕， $\tau_{0}$ は時定数であり, $R_{\mathrm{ct}}$ と $C_{\mathrm{dl}}$ の積で算出される.また， $R_{i}$ および $\tau_{i}$ は，高周波数領域にて 電荷移動抵抗 $R_{\mathrm{ct}}$ および電気二重層容量 $C_{\mathrm{dl}}$ から構成される容 量性半円より低い周波数で示される複数の緩和過程を示す抵 抗および時定数パラメータである7). 上記の方法で各時点に おける電極インピーダンス軌跡からパラメータ $R_{\mathrm{ct}}$ を決定した。

Fig.9には(1)式を用いて算出した各試料の電荷移動抵抗 $R_{\mathrm{c} 1}$ および電気二重層容量 $C_{\mathrm{dl}}$ を示した. 各試料の $R_{\mathrm{cl}}$ はMIM材で は $526 \times 10^{-4} \Omega \cdot \mathrm{m}^{2}$, Sample A では $10.7 \times 10^{-4} \Omega \cdot \mathrm{m}^{2}$, Sample B では $4.75 \times 10^{-4} \Omega \cdot \mathrm{m}^{2}$ であった。この結果からも同様に MIM 材を基準に多孔質材を比較したところ, Sample Aでは $1 / 49$ 倍
に減少し，Sample B では1/111 倍に減少した。一方，各試料 の $C_{\mathrm{dl}}$ は MIM 材では $120 \mu \mathrm{F} \cdot \mathrm{m}^{-2}$, Sample A では $372 \mu \mathrm{F} \cdot \mathrm{m}^{-2}$, Sample Bでは $13330 \mu \mathrm{F} \cdot \mathrm{m}^{-2}$ を示した. この結果からも同様に MIM 材を基準に多孔質材を比較したところ，Sample A では 31 倍に増加し, Sample Bでは 111 倍に増加した。必ずしも厳 密ではないが, Sample A および Sample B ともに $R_{\mathrm{ct}}$ の減少分 が $C_{\mathrm{d} 1}$ の増加分となっている. このことより, Sample A およ びSample B ともに反応面積の増加により， $R_{\mathrm{ct}}$ の減少と $C_{\mathrm{dl}}$ の 増加に浪淀量的に対応しているものと考えられる.

そこで, 電極インピーダンス測定より得られた $R_{\mathrm{ct}}$ の逆数の 值 $R_{\mathrm{ct}}{ }^{-1}$ と Fig.4で得られた $I_{\text {corr }}$ の值を比較し Fig.10に示した. これまでと同様にMIM材を基準に多孔質材を比較した結果, Sample A では分極曲線の場合が 72 倍であるのに対し, 電極 インピーダンス測定の場合は49倍であった.一方, Sample B
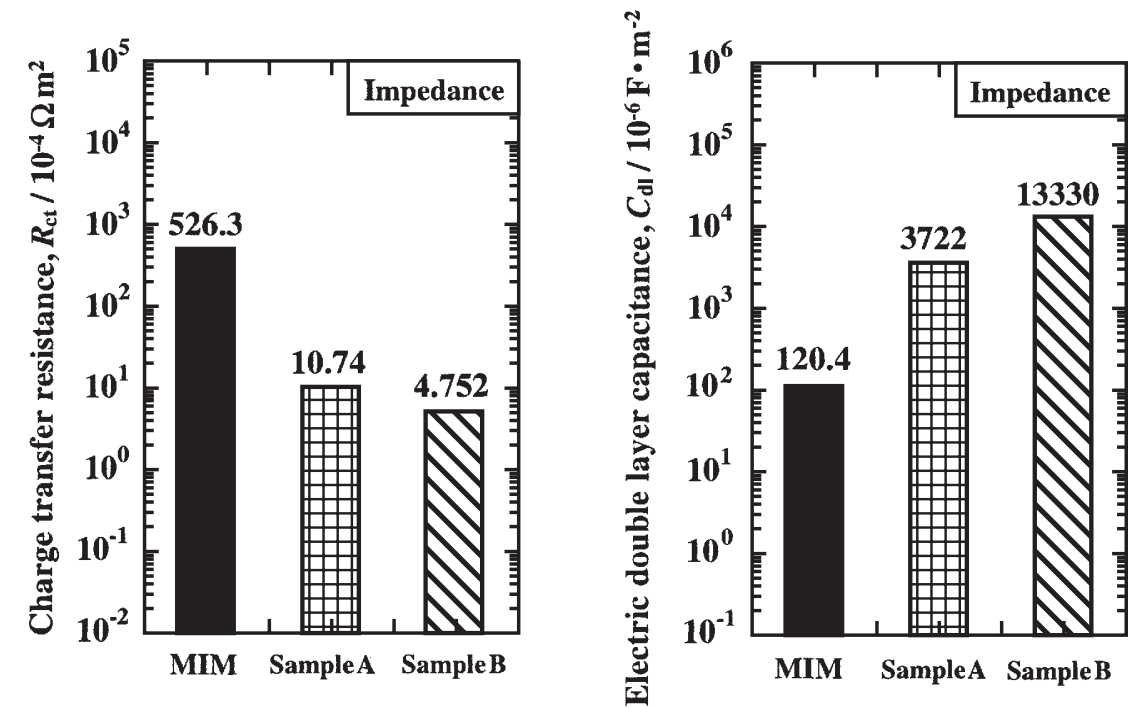

Fig.9 Charge transfer resistance $R_{\mathrm{ct}}$ and Electric double layer capacitance $C_{\mathrm{dl}}$ of Type 316 stainless steels produced by MIM and PSH-MIM process.
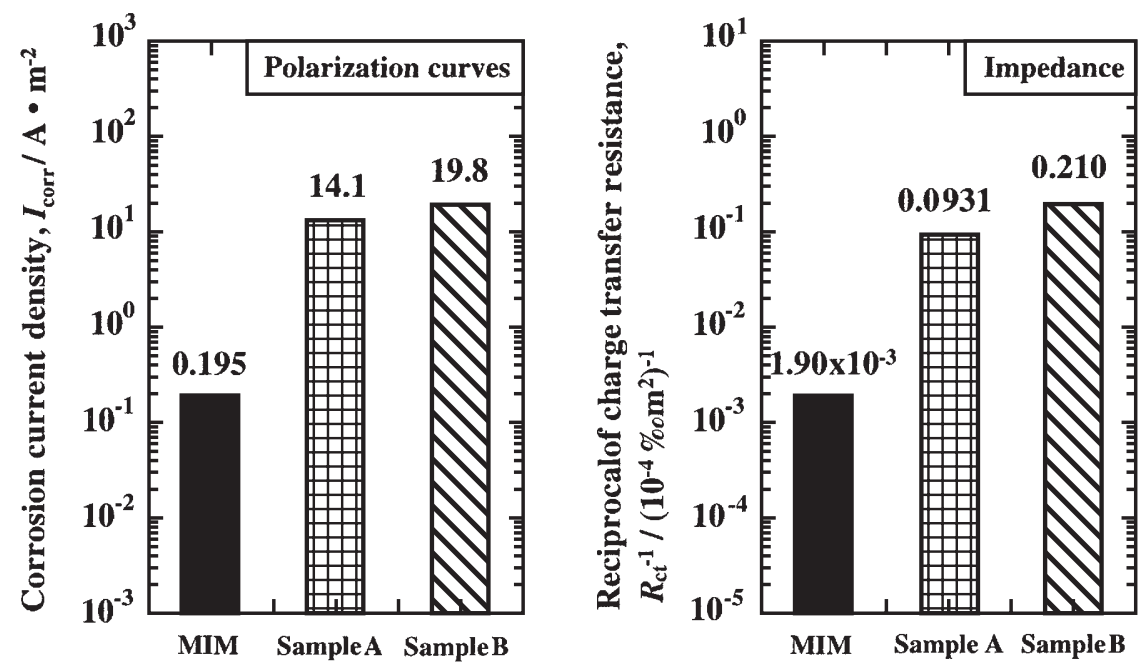

Fig.10 Corrosion current density $I_{\text {corr }}$ and Reciprocal of charge transfer resistance $R_{\mathrm{ct}}{ }^{-1}$ of Type 316 stainless steels produced by MIM and PSH-MIM process. 
では分極曲線の場合が 102 倍であるのに対し，インピーダン ス測定の場合が 110 倍であった．以上の結果から分極曲線の 結果とインピーダンス測定の結果はほぼ類似した傾向を示し， 反応面積の増加による腐食速度の増加が考えられる.

次に Sample A および Sample B が面積の増加による腐食速 度の増加を確認するため, Fig.11に各試料の $\tau_{0}$ の值を示した。 $\tau_{0}$ は, 上述のように電荷移動抵抗 $R_{\mathrm{ct}}$ 之電気二重層容量 $C_{\mathrm{dl}}$ の 積であり，面積の大きさに依存しないパラメータである. MIM 材では $0.0634 \mathrm{~s}$, Sample A では $0.0400 \mathrm{~s}$, Sample B では $0.0633 \mathrm{~s}$ を示した. 従って MIM 材と多孔質材では，ほぼ同等 の值が得られた. 以上のことから活性態領域に㧈いて, 電極 インピーダンス測定で得られた電荷移動抵抗 $R_{\mathrm{cl}}$ は表面積の違 いにのみ依存していると考えられる。

3.4 クーロスタット法による測定

これまでの結果を検討するために, 電極インピーダンスに

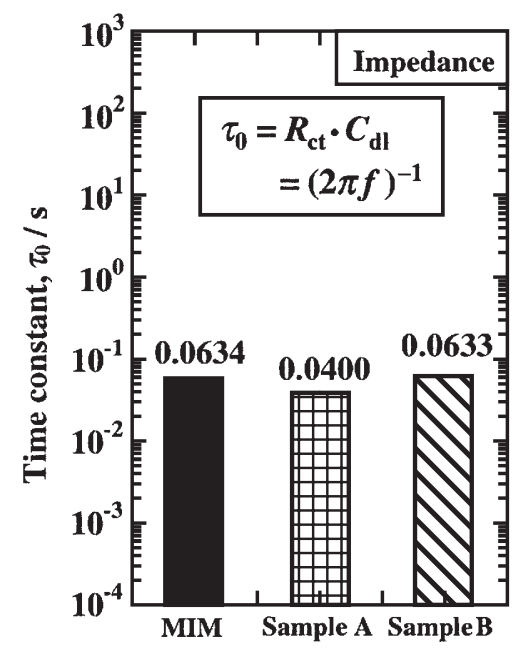

Fig.11 Time constant $\tau_{0}$ of Type 316 stainless steels produced by MIM and PSH-MIM process.

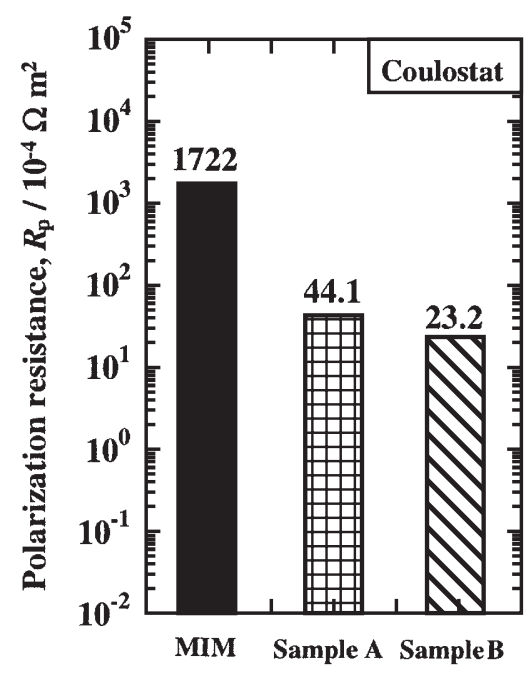

相当する方法としてクーロスタット法8 を用い，比較を行っ た. Fig.12には，この測定より得られるパラメータである分 極抵抗 $R_{\mathrm{p}}$ および電気二重層容量 $C_{\mathrm{d}}$ を求めるための模式図を 示した. 水中で平衡状態にある試料金属に，その電位が正ま たは負に微少 $(<10 \mathrm{mV})$ 変化する程度, 瞬時に任意の電荷を与 えると, 一旦生じた過電圧は指数関数的に減衰する. この減 衰曲線の接線と (2) 式，(3) 式からパラメータである分極抵抗 $R_{\mathrm{p}}$ および電気二重層容量 $C_{\mathrm{d}}$ の導出を行った.

$$
\begin{aligned}
& \log \eta_{t}=\log \eta_{0}-t / 2.303 C_{d} R_{p} \\
& Q=C_{d} \eta_{0}
\end{aligned}
$$

ここで $\eta_{1}$ は過電圧, $\eta_{0}$ は電荷を与えた直後の過電圧, $t$ は測 定時間， $Q$ は試料電極に与えた電荷量である.

Fig.13には上記の方法を用いて算出した各試料の分極抵抗 $R_{\mathrm{p}}$ および電気二重層容量 $C_{\mathrm{d}}$ を示す. 各試料の $R_{\mathrm{p}}$ は $\mathrm{MIM}$ 材で は $1722 \times 10^{-4} \Omega \cdot \mathrm{m}^{2}$, Sample A では $44.1 \times 10^{-4} \Omega \cdot \mathrm{m}^{2}$, Sample Bでは $23.2 \times 10^{-4} \Omega \cdot \mathrm{m}^{2}$ を示した.この結果からも同様にMIM 材を基準に多孔質材を比較したところ, Sample Aでは1/39倍 に減少し, Sample Bでは $1 / 74$ 倍に減少している. 一方, 各試料

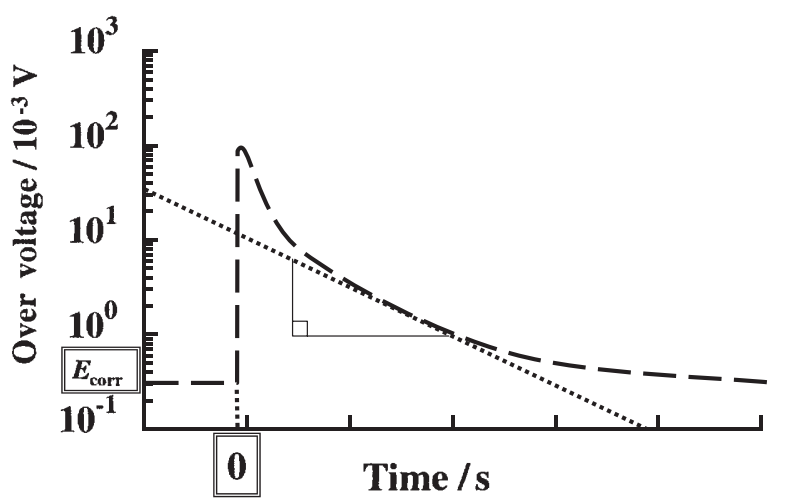

Fig.12 Schematic diagram of the measurement of the Coulostat.

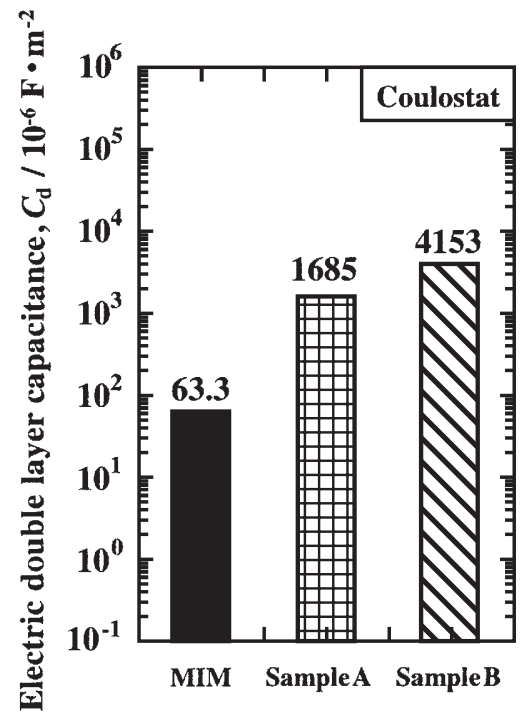

Fig.13 Polarization resistance $R_{\mathrm{p}}$ and Electric double layer capacitance $C_{\mathrm{d}}$ of Type 316 stainless steels produced by MIM and PSH-MIM process. 
の $C_{\mathrm{dl}}$ は MIM 材の場合 $63.3 \mu \mathrm{F} \cdot \mathrm{m}^{-2}$, Sample A では $1685 \mu \mathrm{F}$. $\mathrm{m}^{-2}$, Sample Bでは $4153 \mu \mathrm{F} \cdot \mathrm{m}^{-2}$ を示した. この結果からも同 様に MIM 材を基準に多孔質材を比較したところ, Sample A では 27 倍に増加し, Sample B では66倍に増加した。これら 各パラメータの結果は, Fig.9に示した電極インピーダンスの 結果と類似した傾向を示している.このことからもMIM材と 多孔質材では, クーロスタット法においても電極インピーダ ンスと類似した結果を確認できた.

そこで, Fig.14にはFig.9に示した電極インピーダンス測定 より求めた電荷移動抵抗 $R_{\mathrm{c}}$ と, ク一ロスタット法による測定 より求めた分極抵抗 $R_{\mathrm{p}}$ を示した. これまでと同様に MIM 材 を基準に多孔質材を比較した結果, Sample Aについては, イ ンピーダンス測定の結果が $1 / 49$ 倍であるのに対し, クーロス タットによる測定の結果が1/39倍であった.一方 Sample Bで はインピーダンス測定の結果が $1 / 111$ 倍であるのに対し，
クーロスタットによる測定の結果が1/74倍であった. 以上の 結果からインピーダンス測定の結果とクーロスタット法によ る測定の結果は, 測定法が違うため値は若干異なるものの, ほぼ類似した傾向を示していた。

Fig.15にはFig.9に示したインピーダンス測定より求めた電 気二重層容量 $C_{\mathrm{dl}}$ とFig.13で得られたクーロスタット法による 測定より求めた電気二重層容量 $C_{\mathrm{d}}$ を示した. これまでと同様 にMIM材を基準に多孔質材を比較した結果, Sample Aでは, 電極インピーダンス測定の結果が31倍を示すのに対し,クー ロスタットによる測定の結果が27倍を示した. 一方Sample B では電極インピーダンス測定の結果が 111 倍示すのに対し, クーロスタットによる測定の結果が66倍を示した. 以上の結 果から電極インピーダンス測定の結果とクーロスタット法に よる測定の結果は, 電気二重層容量についても值は若干異な るものの, ほぼ類似した傾向を示している.
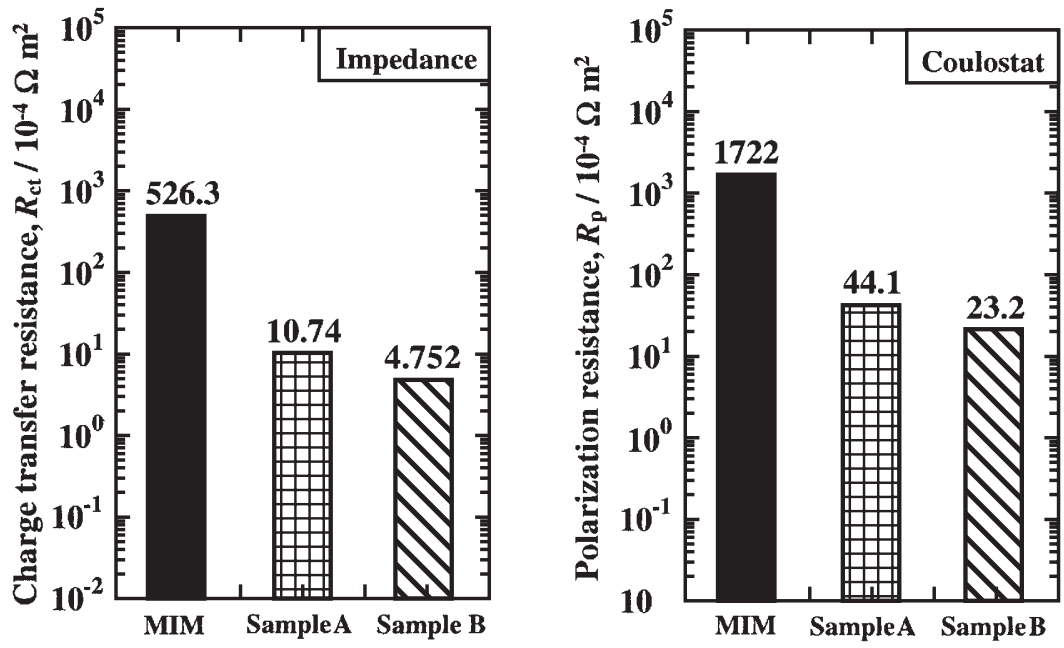

Fig.14 Charge transfer resistance $R_{\mathrm{ct}}$ and Polarization resistance $R_{\mathrm{p}}$ of Type 316 stainless steels produced by MIM and PSH-MIM process.
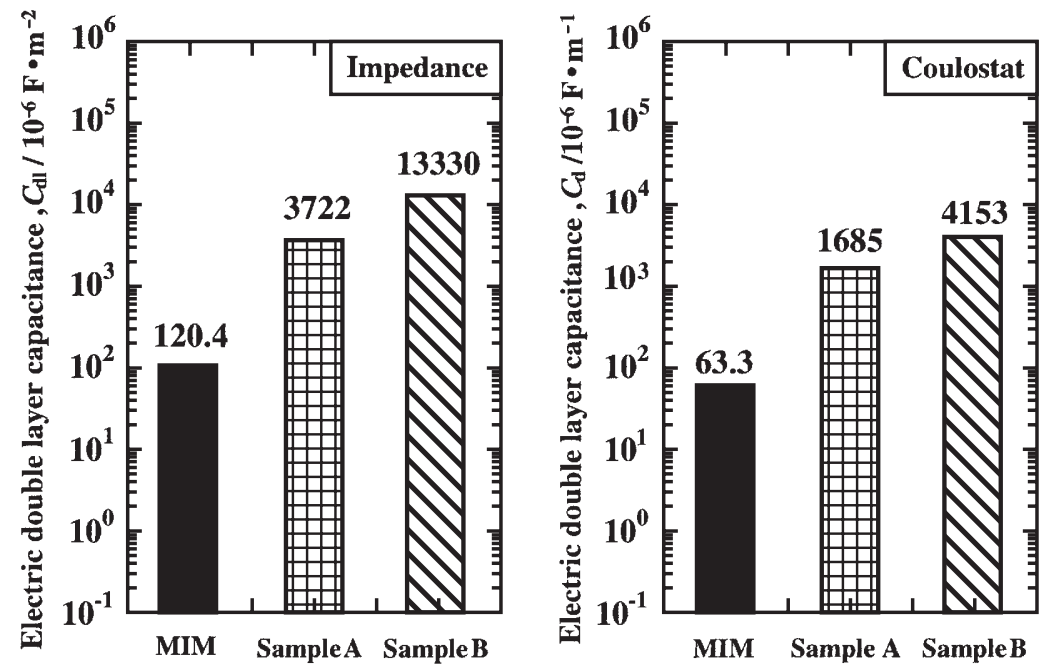

Fig.15 Electric double layer capacitance $C_{\mathrm{dl}}$ and Electric double layer capacitance $C_{\mathrm{d}}$ of Type 316 stainless steels produced by MIM and PSH -MIM process. 

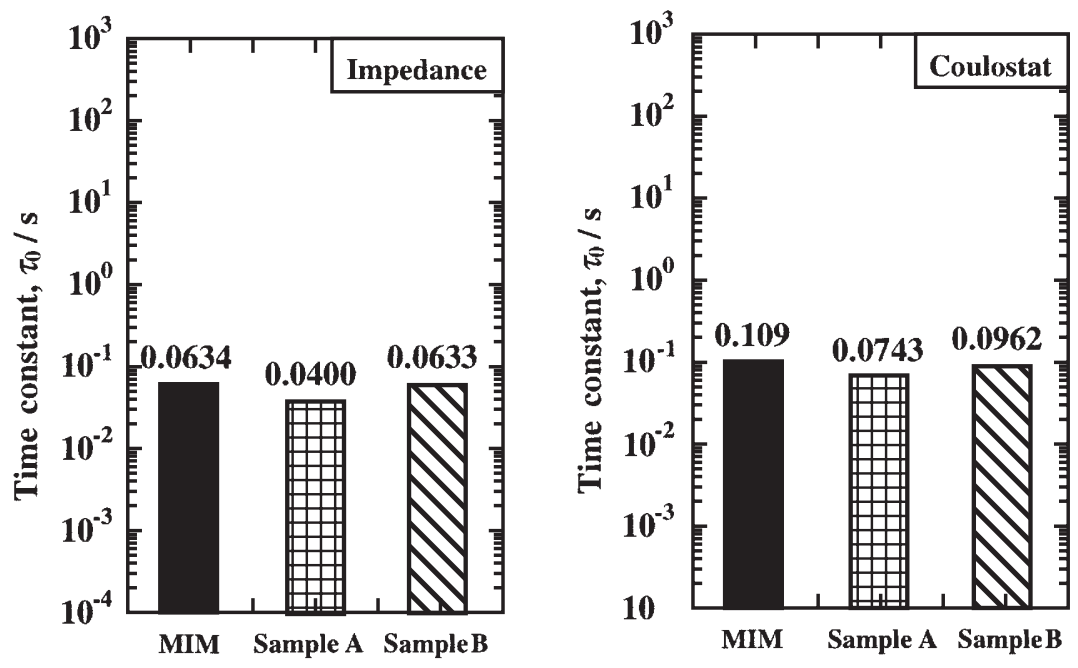

Fig.16 Time constant $\tau_{0}$ of Type 316 stainless steels produced by MIM and PSH-MIM process.

同様にして電極インピーダンス測定とクーロスタット法に よる測定から得られた時定数 $\tau_{0}$ の結果を Fig.16に示した. $\tau_{0}$ においても測定法の違いにより各試料の值は異なるものの, 同じ測定法では各試料で傾向が一致した．以上のことより， クーロスタット法の結果からも $R_{\mathrm{ct}}$ は表面積の大きさに依存し ていることが考えられる。

$$
4 \text { まとめ }
$$

本報の主要な結果を要約すると次の通りである，

(1) ポーラス金属は, 組織が多孔質であり, 反応面積が大きい ために, 溶液は試料内部まで浸透し, 全体的に腐食が進行 する.

(2) 分極曲線測定, EIS測定, クーロスタット法による測定の 結果から, PSH-MIM 材は MIM 材に比べ見かけの腐食速 度が大きいが，これは表面積に強く依存している。

(3) EIS 測定およびクーロスタット法の電気化学的測定は, PSH-MIM 材の腐食速度を測定する有効な手段である.

\section{文献}

1) M. Matsuda and H. Miura: "Application of Heterogeneous Microstructure to Ultrahigh Strengthening Sintered Low Alloy Steels", Proceeding of 2000 Powder Metallurgy World Congress, (2000)20-23.

2) H. Miura: "Fabrication of High Performance Sintered Materials through PIM", Proceeding of 2000 Powder Metallurgy World Congress, (2000)315-319.

3) S. Sunada, K. Majima, Y. Miyazaki, and T. Hasegawa: "Evaluation of Pitting Corrosion Behavior of Sintered SUS444 Stainless Steel in $\mathrm{MgCl}_{2}$ Solution", J. Jpn. Soc. Powder Powder Metallurgy, 51 (2004)451-457.

4) S. Sunada, K. Majima, and T. Matsuda: "Dissolution Behavior of SUS304 Stainless Steel due to General Corrosion in $\mathrm{H}_{2} \mathrm{SO}_{4}{ }^{-}$
$\mathrm{NaCl}$ Aqueous Solution", J. Jpn. Soc. Powder Powder Metallurgy, 52(2005)530-536.

5) S. Sunada, K. Majima, S. Ishida, K. Kanno, and Y. Takeda: "Influence of the Manufacturing Process on Corrosion Resistance of Sintered SUS304 Stainless Steel as Mechanical Structural Material", J. Jpn. Soc. Powder Powder Metallurgy, 52(2005) 537-543.

6) S. Sunada, K. Majima, S. Ishida, K. Kanno, and Y. Takeda: "Influence of Shot Peening on Corrosion Resistance of Sintered SUS304 and SUS316 Stainless Steel", J. Jpn. Soc. Powder Powder Metallurgy, 52(2005)544-550.

7) S. Sunada, T. Yamamoto, K. Majima, and N. Nunomura: "Comparison of Corrosion Behavior among I/M, P/M and MIM SUS304 Stainless Steels by Electrochemical Method", J. Jpn. Soc. Powder Powder Metallurgy, 52(2005)551-561.

8) K. Kanno, M. Suzuki, and Y. Sato: "An Application of Coulostatic Method for Rapid Evaluation of Metal Corrosion Rate in Solution", J. Electrochem. Soc., 125(1978) 13891393.

9) K. Sugimoto: "Electron Transfer Chemistry of Materials", The Japan Institute of Metals, (2003)123-127.

10) E. McCafferty: "Validation of corrosion rates measured by the Tafel extrapolation method", Corrosion Science, 47(2005) 3202-3215.

11) K. Sugimoto and M. Yuki: "Electrochemical Impedance Diagrams of Alloy 600 at Active-Passive Transition Potentials", J. Japan Inst. Metals, 46(1982)1156-1163.

12) A. Nishikata, Li zhong Le, and T. Tsuru: "Symposium on Electrochemical Impedance Spectroscopy", Japan Society of Corrosion Engineering, (2004) 1-10.

13) K. Sugimoto: "Fundamental Aspects of Localized Corrosion", J. the Surface Finishing Society of Japan, 32(1981)355-365. 
14) K. Sugimoto: "Electron Transfer Chemistry of Materials", The Japan Institute of Metals, (2003)134-138.

15) I. Epelboin, M. Keddam, and J. C. Lestrde: "Faradaic Impedances and Intermediates in Electrochemical Reactions", Faraday Disc. Chem. Soc., 56(1974)264-275.

16) I. Epelboin and M. Keddam: "Faradaic Impedances: Diffusion Impedance and Reaction Impedance", J. Electrochem. Soc., 117(1970) 1052-1056.

17) I. Epelboin, M. Keddam, and H. Takenouti: "A Model of the Anodic Behavior of Iron in Sulphuric Acid Medium", Electrochemica Acta, 20(1975)913-916.

18) R.D. Armstrong: "Relaxation Times for Adsorption Coupled with A Homogeneous Reaction in Solution", J. Electroanal. Chem., 22(1969)49-53.

19) R.D. Armstrong and M. Henderson: "Impedance Plane Display of a Reaction with an Adsorbed Intermediate", J. Electroanal. Chem., 39(1972)81-90.

20) R.D. Armstrong and R.E. Firman: "Impedance Plane Display of a Reaction with a Solution Soluble Intermediate", J.
Electroanal. Chem., 45(1973)3-10.

21) M. Keddam, O.R. Mattos, and H. Takenouti: "Reaction Model for Iron Dissolution Studied by Electrode Impedancei. I. Experimental Results and Reaction Model", J. Electrochem. Soc., 128(1981)257-266.

22) M. Keddam, O.R. Mattos, and H. Takenouti: "Reaction Model for Iron Dissolution Studied by Electrode Impedance II. Determination of the Reaction Model", J. Electrochem. Soc., 128(1981) 266-274.

23) M. Keddam, J.-F. Lizee, C. Pallotta, and H. Takenouti: "Electrochemical Behavior of Passive Iron in Acid Medium I. Impedance Approach", J. Electrochem. Soc., 131(1984)20162024.

24) Y. Hara: "Symposium on Electrochemical Impedance Spectroscopy", Japan Society of Corrosion Engineering, (2004) 19-28.

25) M. Itagaki and K. Watanabe: "Relation between Adsorption and Electrochemical Impedance in Anodic Dissolution of Metal", DENKI KAGAKU, 65(1997)758-764. 